\title{
Ritual deposits of the Petrești culture in South-Western Transylvania
}

\begin{abstract}
This article presents archaeological discoveries of ritual pits framed in Petrești culture, discovered in western and south-western Transylvania. The ritual of consecrating the dwellings, through banquets dedicated to fertility and fecundity, is so well known at the time around the Apuseni Mountains that is spreads in cultural environments, west of them.
\end{abstract}

Keywords: ritual deposit, Eneolithic, from Petrești culture, discovered in western and southwestern of Transylvania.

In $1984^{1}$, archaeological excavations were carried out in the border of Uioara de Jos (I. Hica and H. Ciugudean) (Fig. 1), the complete research of the incineration cemetery from the VII-VIII AD centuries identified on the place called Pârloage, in $1963^{2}$. Various traces of habitation have also been identified here, including an urn incineration tomb belonging to the Wietenberg culture ${ }^{3}$ and archaeological materials belonging to the late Hallstatt ${ }^{4}$.

Between 1985-1986, at Gruiul lui Șip, a settlement with several levels of habitation was researched, starting from the developed Eneolithic (Petrești culture), continuing with the late Eneolithic (Coțofeni culture), early Bronze III (Iernut type discoveries), middle Bronze (Wietenberg) and late Bronze (Noua materials, preGáva and Gáva), ending with a level belonging to the VII-VIII centuries AD, contemporary with the cemetery from Pârloage (the research results were only partially published in various studies ${ }^{5}$.

\footnotetext{
*"Lucian Blaga" University of Sibiu; sabinadrian.luca@ulbsibiu.ro, Brukenthal National Museum of Sibiu; sabin.luca@brukenthalmuseum.ro

1 Sabin Adrian Luca, Horia Ciugudean, ”O depunere rituală aparținând culturii Petrești descoperită la Uioara de Jos". In: Apulum 55 (2018), p. 9-22.

2 Vasile Moga, Horia Ciugudean (ed.), Repertoriul arheologic al judeţului Alba, (Alba Iulia: 1995), 196.

${ }^{3}$ Horia Ciugudean, "Noi descoperiri funerare aparţinând culturii Wietenberg". In: Apulum 26 (1989), 69-77, 72, Fig. 2/1, 4.

${ }^{4}$ Horia Ciugudean, Cercetări privind epoca bronzului şi prima vârstă a fierului în Transilvania, (Alba Iulia: 1997).

${ }^{5}$ Ioan Al. Aldea, Horia Ciugudean," Obiecte din cupru şi bronz recent descoperite pe teritoriul judeţului Alba". In: Apulum 25 (1988), 79-81; Horia Ciugudean, The Hallstatt A period in central Transylvania, (Alba Iulia: 1994), 25-40. The Petrești type settlement has unpublished so far
} 
The Petrești inhabitation is not very consistent and continuous as a layer. The researched features were in sections I. III and IV. Within the perimeter of section IV/1985, a surface dwelling with massive remains of polished clay was partially unveiled, while section I intersected the pit of a large hut, inside which was found a hearth, built on a" layer" formed from ceramic fragments.

The most important feature belonging to the Petrești culture is represented by the pit with ritual deposits from section III. It deepened to about $-1,40 \mathrm{~m}$, in the reddish-yellowish clay level, sterile from archaeological point of view. Unfortunately, other stratigraphic or positioning observations of the archaeological feature were not available to us ${ }^{6}$.

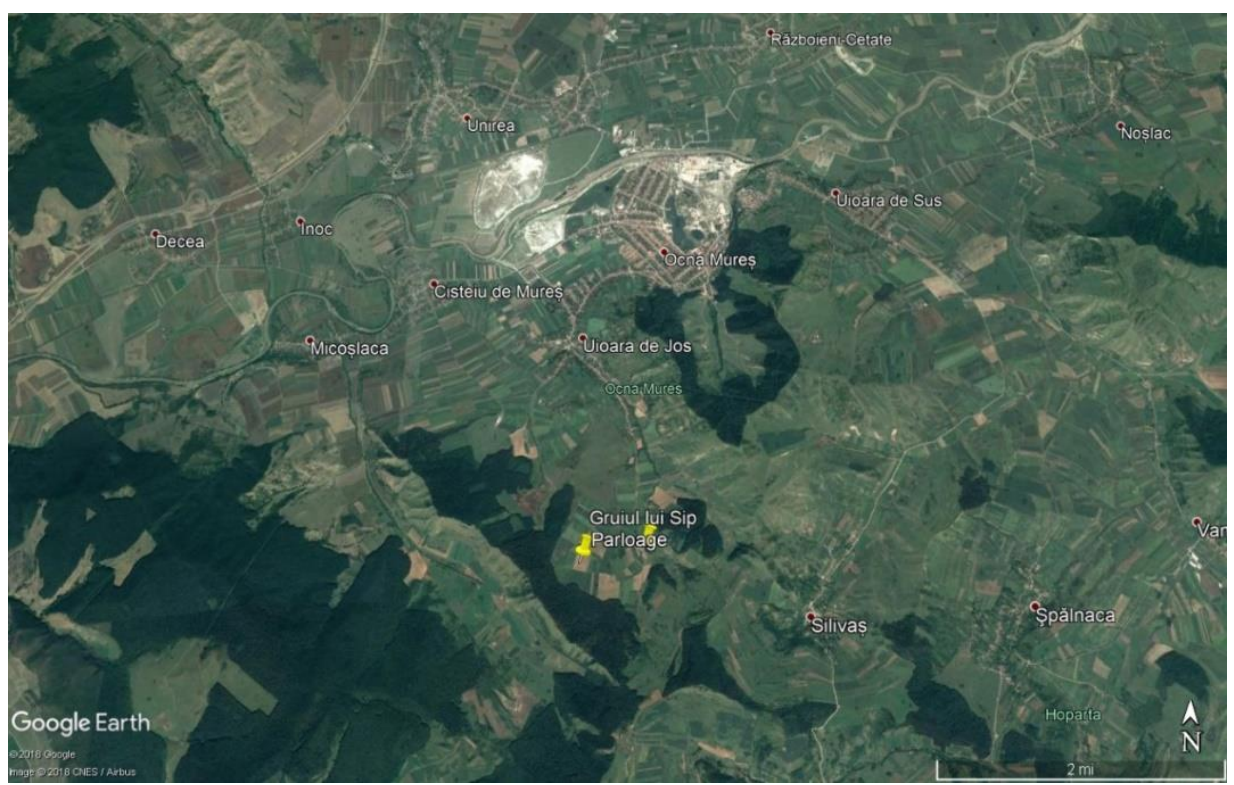

Fig. 1. Location of the investigated sites in the area of Ocna Mureș.

In its upper part, the pit was covered with several fragments of stone mills, like a ritual deposition from Turdaș-Luncă, the dwelling-sanctuary number 2, the Petrești culture ${ }^{7}$.

We find that in Turdas it was about a special feature, the foundation of the Petrești sanctuary, consisting of 8 mills (broken and buried with the active part down) and a massive stone bovid head (buried face up) ${ }^{8}$.

\footnotetext{
${ }^{6}$ Sabin Adrian Luca, Horia Ciugudean," O depunere ritual", 9.

${ }^{7}$ Sabin Adrian Luca, Așezări neoliicee pe Valea Mureșului (II). Noi cercetări arheologice la TurdașLuncă. Campaniile anilor 1992-1995, (Alba Iulia: 2001), 88-91.

${ }^{8}$ Sabin Adrian Luca, Așezări neoliicee pe Valea Mureșului (II), 89-90, Fig. 6.
} 
The association of whole vessels with broken mills is specific to the ritual deposits from the European Neolithic ${ }^{9}$.

From the bottom of the pit from Uioara de Jos-Gruiul lui Șip, several whole or completable vessels, a piercer, half a bi-tronconic clay spindle piece, a stone polisher for pottery (?) were recovered and more animal bones ${ }^{10}$. ritual pit $^{11}$.

We further present the description of the ceramic vessels found inside the

Vessel number 1 is an amphora with a bulging belly and a high neck (Photos $1-2$, Pl. I) ${ }^{12}$. The clay from which the vessel was made is fine, brick-like, and very well fired. The slip of the vessel was affected by the storage conditions in the ground, being partially dropped and without specific shine.

As a form, the vessel has analogies in the monography written by I. Paul ${ }^{13}$.

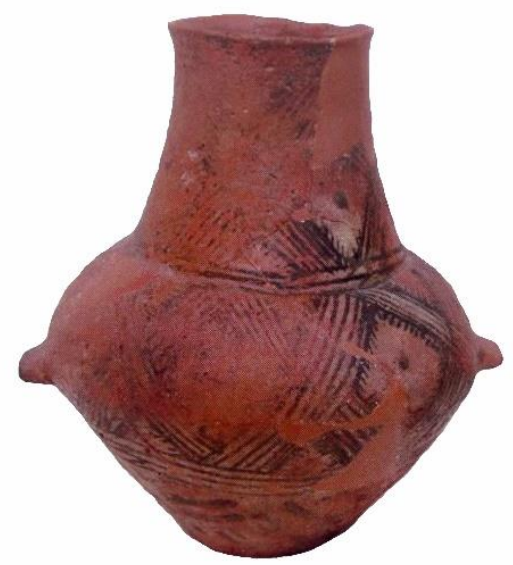

Photo 1. Uioara de Jos-Gruiul lui Şip, Alba County. Painted amphora, Petrești culture (Vessel 1).

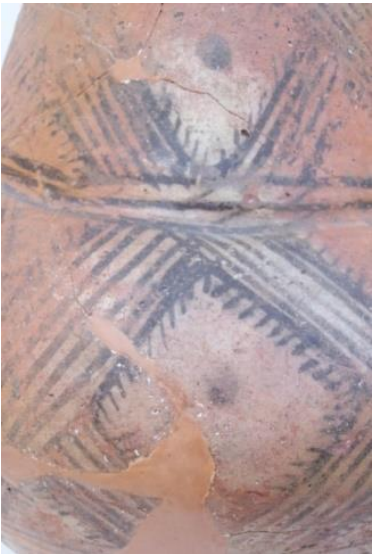

Photo 2. Uioara de Jos-Gruiul lui Şip, Alba County. Painted amphora, Petrești culture. Detail with the belly of the vessel.

\footnotetext{
9 J. Graefe, C. Hamon, C. Lidström-Holmberg, C. Tsoraki, S. Watts," Subsistence, social and ritual practices: querns deposits in the Neolithic societies of Europe". In: Du matériel au spirituel, S. Bonnardin (ed.) (Antibes: 2009), 29-38.

${ }^{10}$ Sabin Adrian Luca, Horia Ciugudean," O depunere ritual", 11.

${ }^{11}$ Sabin Adrian Luca, Horia Ciugudean," O depunere ritual", 11-20.

${ }^{12}$ Sabin Adrian Luca, Horia Ciugudean," O depunere ritual", 11-12, Fig. 2. Named - generally - pots, at Paul 1992, Pl. XXIX, Petrești culture, Phase A or - maybe - AB.

${ }^{13}$ Iuliu Paul, Cultura Petreşti, (București: 1992), Pl. XXVII/1, 5-6; XXVIII/15.
} 


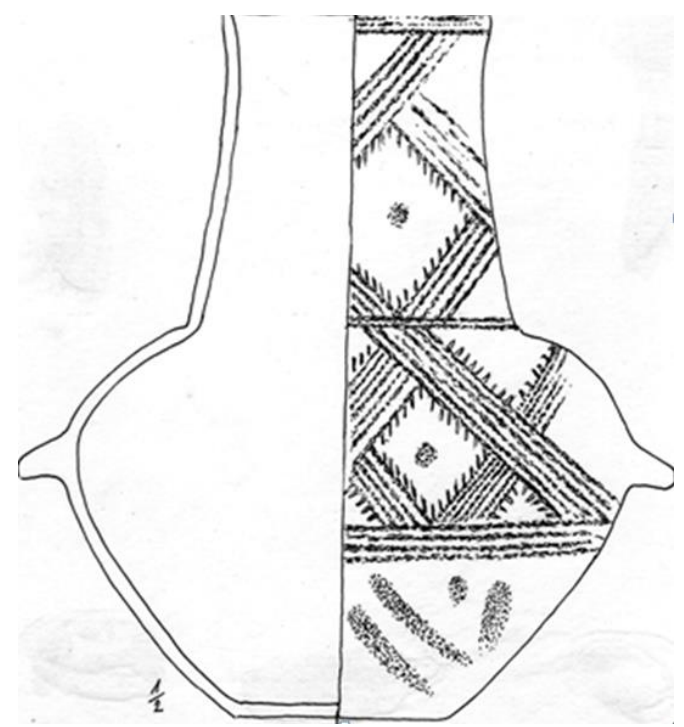

Pl. I. Uioara de Jos-Gruiul lui Şip, Alba County. Painted amphora, Petrești culture (Vessel 1).

The lower register (below the four lines surrounding the vessel, towards the bottom, from the middle of the belly, of the distance between it and the handles) is made of thick, parallel lines, whose groupings are arranged in" rafters". Between the rhomboid rafters, on the unpainted rhombus, is a painted point. The lower register is like that of a vessel from Alba Iulia-Lumea Nouă belonging to the same Petrești culture $^{14}$. The median register is located between the four-line band that borders, at the top, the lower register and the three parallel lines that surround the twinning between the belly and the neck. On the neck and on the upper part of the middle part you can see - in some places - a white font (poorly preserved), over which lie the painted ornaments in dark color.

The ornament of the middle and upper register is made of strips of parallel lines (5-7 lines), arranged in a zigzag and intersected. Their weaving gives the geometric shape of diamonds. The empty spaces inside the diamonds are filled with a dot, made with the same color ${ }^{15}$.

\footnotetext{
${ }^{14}$ Mihai Gligor, Aşezarea neolitică şi eneolitică de la Alba Iulia - Lumea Nouă în lumina noilor cercetări, (Cluj-Napoca: 2009), Pl. CLIX, CLXIII.

${ }^{15}$ Analogies: more dots: Iuliu Paul, Cultura Petreşti, Pl. XXXVII - vessel from the middle of the plate, Pl. XL/3a (inside), Pl. XLI/5b (inside) and Pl. XLIV/2; one dot: Iuliu Paul, Cultura Petreşti, Pl. XXXVII/1b; Pl. XLVIII/4 - elongated; Mihai Gligor, Aşezarea neolitică şi eneolitică de la Alba Iulia - Lumea Nouă, Pl. CXLIII/1: at 1a (outside, one dot) and at 1b (inside, more geometric arranged dots)). The edges of the strips are accentuated by short, parallel cuts - painted (analogies: Iuliu Paul, Cultura Petreşti, Pl. XXXI/16 (right - down), Pl. XLI/1a, 2a, 3, 5a (Petrești culture); Ceramica neolitică. Meşteşug, artă, tradiţie. Trei milenii de spiritualitate preistorică - catalog de expoziţie, (Piatra Neamţ: 1995), the cover, left vessel (Cucuteni culture).
} 
In my opinion, this vessel is the central part of the cultic feature, in which the sacred liquid is housed. The heigh of the vessel is $30,2 \mathrm{~cm}$, the diameter of the mouth is $10,5 \mathrm{~cm}$, the diameter of the bottom is $9,3 \mathrm{~cm}$ (NMU Alba Iulia, Inv. No. P. 6604).

The second vessel is a bowl with a faired shoulder and neck perpendicular to the careen (Photo 3-4; Pl II) ${ }^{16}$. It also has simple buttons, one at a time, placed on the maximum proximity of the careen. The vessel is made of fine clay, fired, bricklike-yellowish outside and brown yellowish inside, very well smoothed and polished.

As a form, the vessel has analogies in the monograph written by I. Paul ${ }^{17}$. The neck is painted with triangles (one by one with the tip towards the lip or careen," wrapped") filled with short lines (3, 4 or 5 each - those with 3-4 lines are oriented with the tip towards the lip, the triangles, and those with 5 are oriented - the triangles - with the tip towards the lower part of the vessel, more precisely towards the careen).

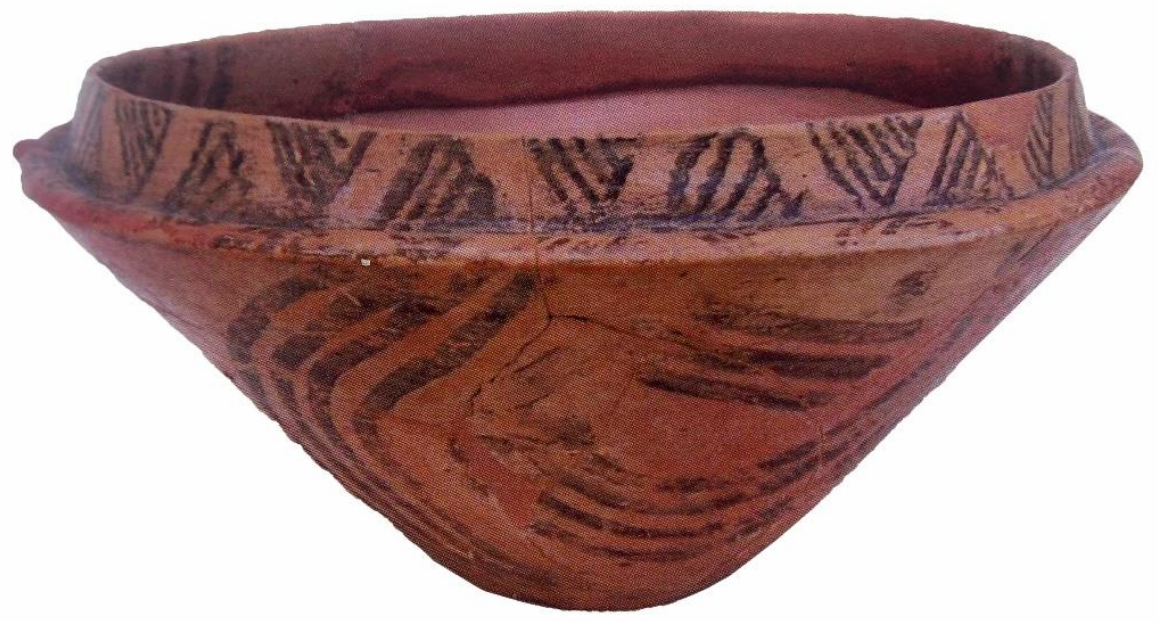

Photo 3. Uioara de Jos- Gruiul lui Şip, Alba County. Painted careened-vessel, Petrești culture (Vessel 2).

\footnotetext{
${ }^{16}$ Sabin Adrian Luca, Horia Ciugudean, ”O depunere ritual”, 12-14, Fig. 3-4.

${ }^{17}$ Iuliu Paul, Cultura Petreşti, Pl. XXIX/careened bowl, Petrești culture, Phase B; Pl. XXIV/28
} 


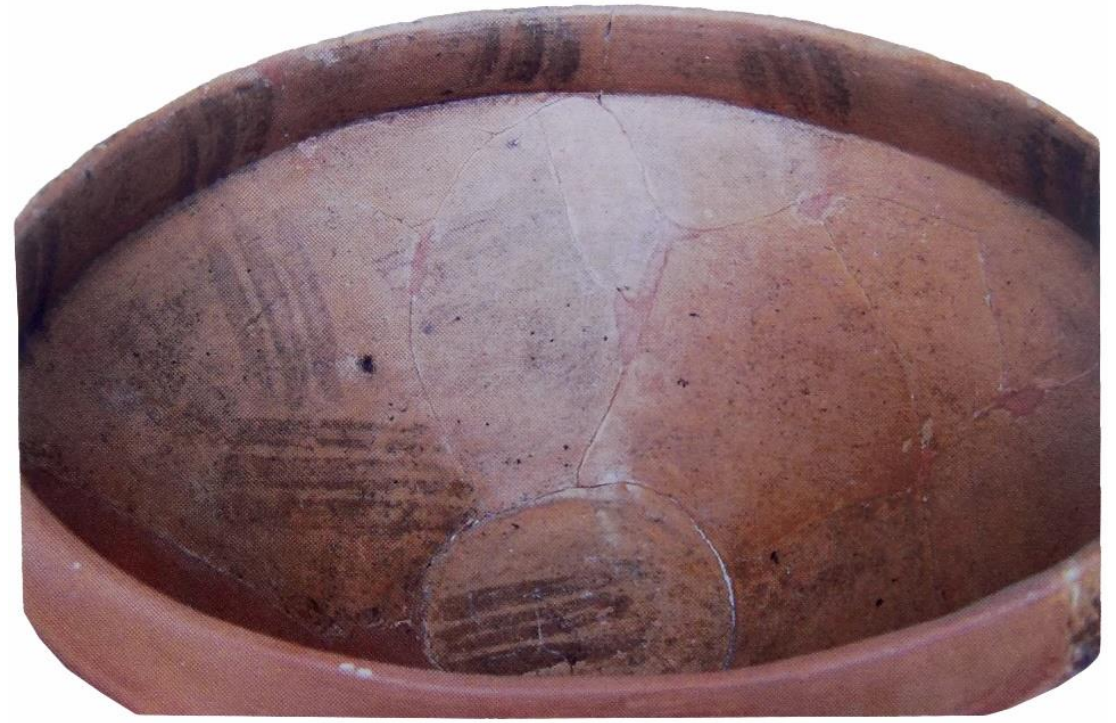

Photo 4. Uioara de Jos-Gruiul lui Şip, Alba County. Painted careened-vessel, Petrești culture (Vessel 2).

The container is painted as follows. Outside, the painting covers - through different registers - the neck, the careen (the part perpendicular to the neck) and the wall of the vessel (from the careen to the bottom) and is black.

The careen is painted along a fine demarcated line with the neck. Next to the triangles are 3-5 very short lines, arranged - again - at opposite angles.

Finally, the part between the careen and the bottom is ornamented with lines 3-4 times thicker than those at the top, arranged 4 - those that are meandering, at complementary angles (one end of the meander is cut, perpendicularly by a short line) - and slightly oblique to the careen - those that fill the space, three, shorter.

Rarely and without and obvious connection with the geometry of the painting is a dot painted with the brush with which the lower part was painted.

The interior of the vessel is painted with the third brush, in my opinion (due to the thickness of the line). Even if its size (of the brush) is about the same as the one with which the lower space of the vessel's face was painted, it draws a line that has the middle untouched by color. The lines are organized in three - both those that adorn the neck, inside, from the careen to the bottom and the bottom (analogies at Paul 1992, outside - Pl. XXXIII/the vessel from the bottom of the plate has the exterior painted almost identical to our vessel; $\mathrm{Pl}$. XLVV/3c ). 


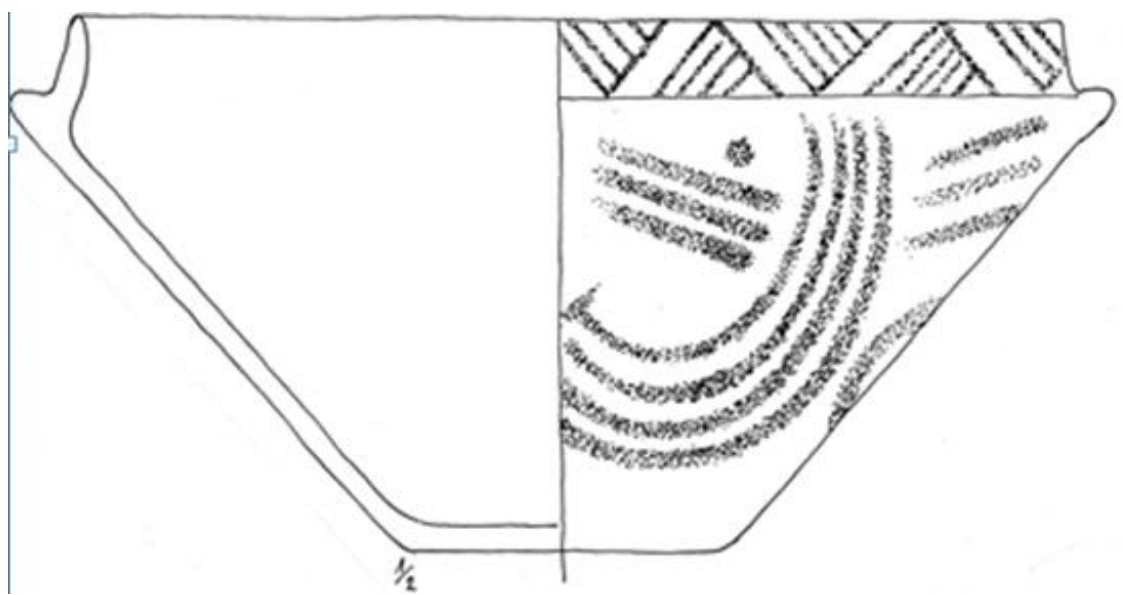

PI. II. Uioara de Jos-Gruiul lui Şip, Alba County. Painted careened-vessel, Petrești culture. The vessel is painted outside and inside (Vessel 2).

The lines that decorate the neck (its back) are three and have a geometric painting direction for half of the vessel and another direction - forming and ideal triangle - on the other half. From the careen to the bottom, the lines are side by side, all three (and on the bottom), being opposite, one group to another, at an angle of about $90^{\circ}$.

The heigh of the vessel is $20 \mathrm{~cm}$, the diameter of the mouth is $35,9 \mathrm{~cm}$ and the diameter of the bottom is $11,7 \mathrm{~cm}$ (NMU Alba Iulia, Inv. No. P. 6605).

The vessel with number 3 is also a bowl with a careened shoulder, like the previous vessel (Photo 5-6; Pl. III) ${ }^{18}$. It no longer has a straight bottom, and its upper part, that of the careen, is slightly inclined to one side, the connection between the neck and the careen not being perfectly straight and the neck being slightly bent towards the inside of the vessel.

Compared to the previous vessel, it looks more unbalanced. It is made of fine clay, brick-like, polished, and very well fired. And this vessel has two buttons, double, which can be imagined as grabbing on the maximum proximity of the careen. As a form, it has analogies in the monograph written by I. Paul ${ }^{19}$.

Like the previous vessels, it is decorated with black paint - like color slightly to brown. The style of the painting is - for the most part - the same as that of the previous vessel, but - as the shape and category show - the vessel is no longer made by a craftsman, as routine as the one who made the previous vessels, so seems to be made especially for this ritual occasion.

\footnotetext{
${ }^{18}$ Sabin Adrian Luca, Horia Ciugudean," O depunere ritual", 14-16, Fig. 5; typologically-stylistically, the vessel can be framed in Phase $\mathrm{AB}$ of the Petrești culture: Iuliu Paul, Cultura Petreşti, Pl. XXIX/careened bowl.

${ }^{19}$ Iuliu Paul, Cultura Petreşti, Pl. XXIV/25, pl. XLI/5b; XLVII/4c; XLVIII/6c
} 
Only the combustion shows the same craftsmanship, so they were fired in the same oven or in the same type of wood to achieve the temperature (at least Vessels 2-4).

On the outside are painted, slightly differently, the same registers as in Vessel 2. The neck is painted with two brush thicknesses, joining 4 parallel lines that meet in a triangle, at $90^{\circ}$, only on the half of the vessel. On the side perpendicular to the neck of the careen, the idea of painting is relatively the same as for Vessel 2. Continue, towards the bottom, the groupings of lines on the neck. The lower part comprises groupings of two or three lines arranged relatively disorganized, but with the intention of suggesting the virtual intersections of the groupings ${ }^{20}$. The painted interior is no longer as well organized, as in the arrangement of the ornamental registers, as in Vessel 2. The lines are made - however - with a brush like the one with which the interior of Vessel 2 was painted.

The lines that decorate the inside of the lip seem to be continued towards the bottom, where, however, there are groupings of short lines, arranged relatively chaotically ${ }^{21}$. The heigh of the vessel is $11 \mathrm{~cm}$, the diameter of the mouth is $19,5 \mathrm{~cm}$, the diameter of the bottom is $8 \mathrm{~cm}$ (NMU Alba Iulia, Inv. No. P. 6606).

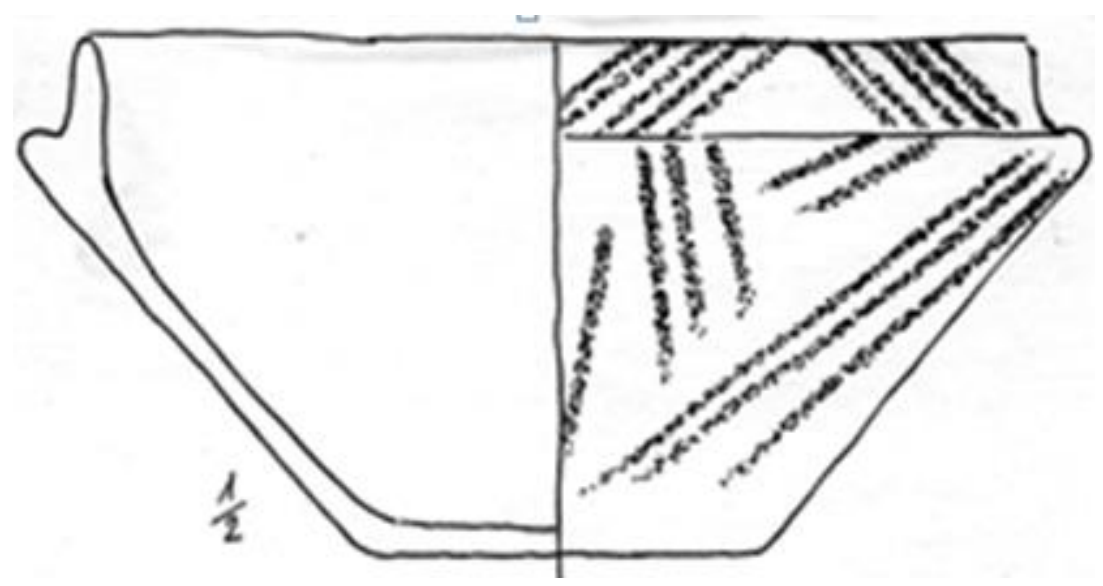

Pl. III. Uioara de Jos-Gruiul lui Şip, Alba County. Painted careened-vessel, Petrești culture. The vessel is painted outside and inside (Vessel 3).

\footnotetext{
${ }^{20}$ Analogies: Sabin Adrian Luca, Tărtăria REDIVIVA, (Alba Iulia: 2016), 181, Fig. 138/1 - exterior part (up), inferior half.

${ }^{21}$ Analogies: Iuliu Paul, Cultura Petreşti, Pl. XLVIII/8c.
} 

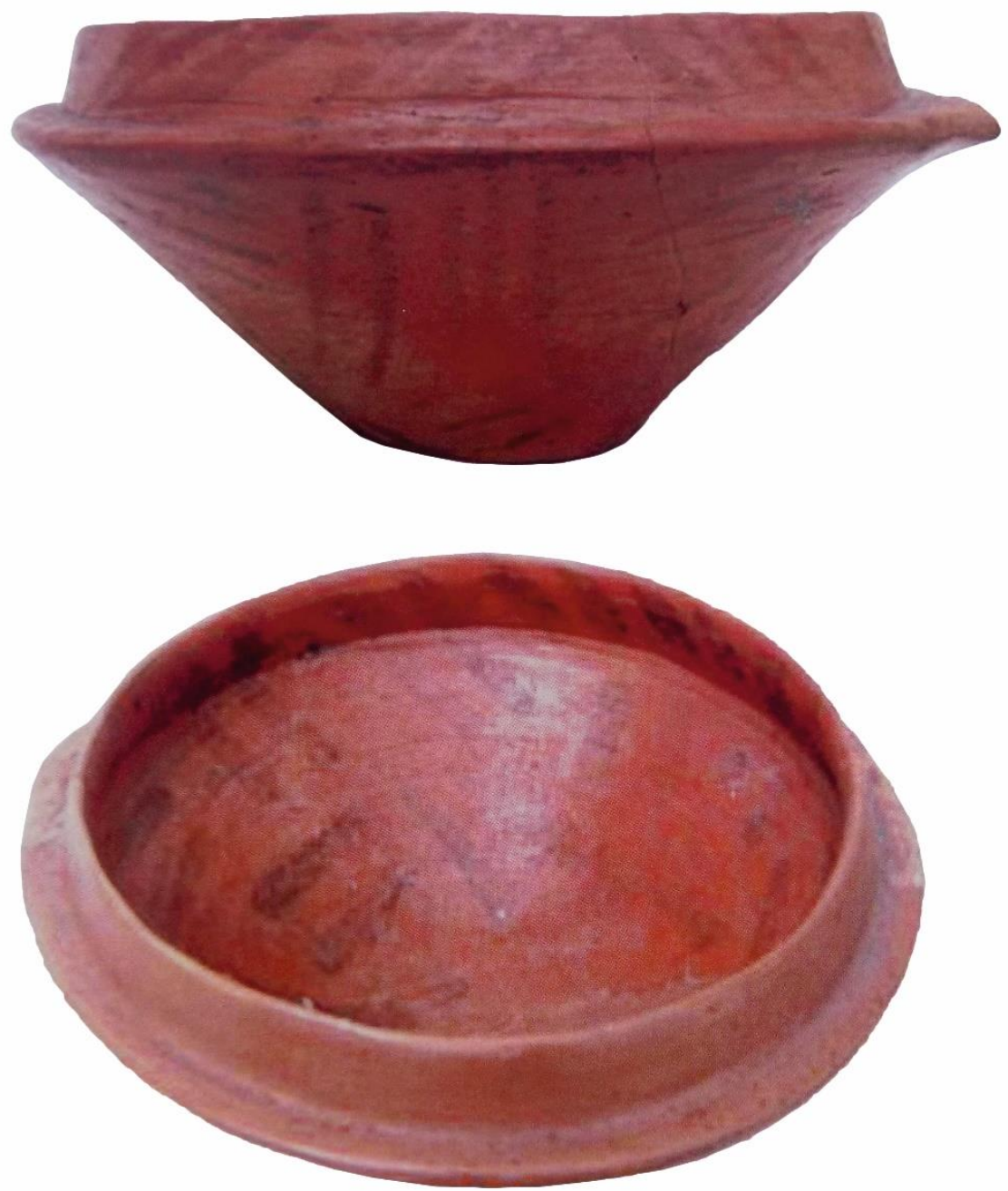

Photo 5. Uioara de Jos-Gruiul lui Şip, Alba County. Painted careened-vessel - exterior part of the Petrești vessel (Vessel 3).

Photo 6. Uioara de Jos-Gruiul lui Şip, Alba county. Painted careened-vessel - interior part of the Petrești vessel (Vessel 3). 
8).

Vessel number 4 is painted bichrome - this time (red and black) $)^{22}$ (Photo

The vessel is complex - in shape - with a high support leg, slightly quadrilateral-rounded, as a section, and with the vessel on the foot (which continues it) difficult to define, as a shape. The walls of the foot are extremely thick with the clay mixed less well, floury, unpolished - but only very well smoothed - and with the painting not having a very good quality, the one - by the way - general in the Petrești culture. Only the firing is of good quality.

The upper part, the vessel itself, was - probably - thrown away with its breaking, as was the base of the foot (the breaking happened, of course, at the time of the final ritual). We also mention that the foot retains a round perforation ${ }^{23}$ towards its upper part and is slightly flared towards the base $\mathrm{e}^{24}$.

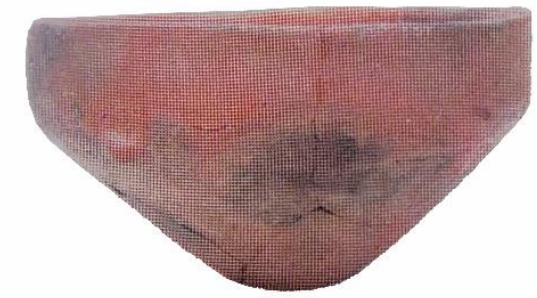

Photo 7. Uioara de Jos-Gruiul lui Şip, Alba County. Bitronconic vessel, Petrești culture (Vessel 5).

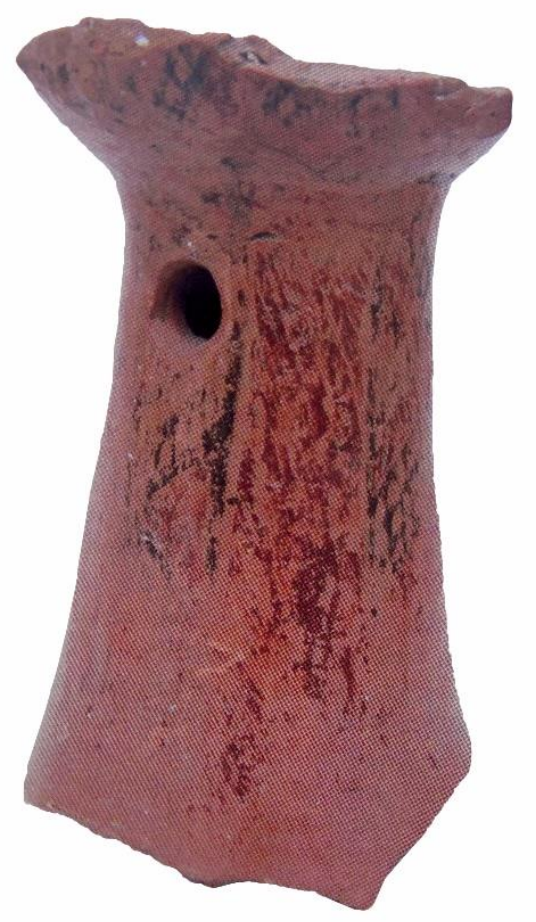

Photo 8. Uioara de Jos-Gruiul lui Şip, Alba County. Bichrome painted vessel base. Petrești culture (Vessel 4).

\footnotetext{
${ }^{22}$ Sabin Adrian Luca, Horia Ciugudean," O depunere rituală", 16-17, Fig. 6; analogies for the form at: Iuliu Paul, Cultura Petreşti, Pl. XXIX/support, Petrești culture, phase B, middle vessel.

${ }^{23}$ Analogies for perforation: Sabin Adrian Luca, Tărtăria REDIVIVA, 46, Fig. 23.

${ }^{24}$ In the monography dedicated to the Petrești culture there are perforated legs with rectangular or quare holes: Iuliu Paul, Cultura Petreşti, Pl. XXVa/9; XXVIII/14; XXIX/support, Petrești culture, Phase AB.
} 
The ornament of the vessel is the painted one. The black painting consists of strips intersected at an angle of $45^{\circ}$ by short cuts. On the vessel, at the top of the support leg they (painted strips) are oblique ${ }^{25}$, and in the bottom (on the foot itself) they are perpendicular to the sole, and filled with bands, either oblique, intersected at an angle of $90^{\circ}$ to the middle of the foot heigh, the band to the upper part of which the perforation is applied; or filled with short lines, intersected by thin bands, perpendicular to its bottom.

Note that at the bottom the red painting completely fills the space of the quadrilateral angle, slightly curved (its corners) of the foot, and at the top it is not possible to define exactly the role of the red painting (and the food is rounded, a more much in section), limiting us only to mention it (NMU Alba Iulia, Inv. No. P. 6605).

Vessel number 5 is a bi-tronconic bowl, with the shoulder perpendicular to the bottom (Photo 7; Pl. IV) ${ }^{26}$.

It is made of black clay with red-brick-like firing marks. The button bowl placed on the shoulder, at the twinning between it and the part facing the bottom. The firing is very good and the temper is quite homogeneous.

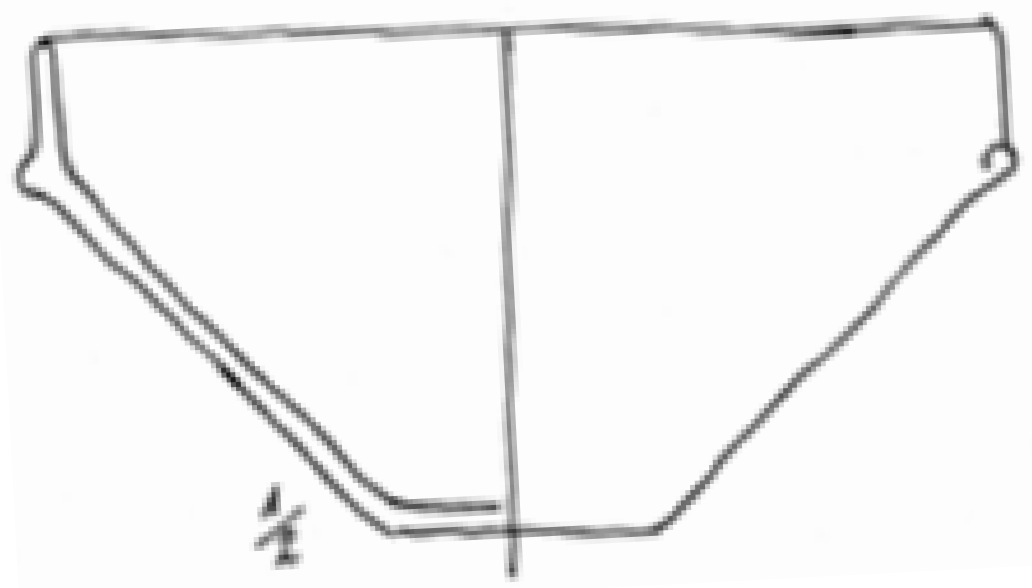

PI. IV. Uioara de Jos-Gruiul lui Şip, Alba County. Bitronconic vessel, Petrești culture. Unpainted (Vessel 5).

The lip of the vessel is slightly wavy, and its general appearance shows that it belongs to semi-fine ceramics, well smoothed, but unpolished. It seems

\footnotetext{
${ }^{25}$ Sabin Adrian Luca, Tărtăria REDIVIVA, 202-203, Fig. 155/4.

${ }^{26}$ Sabin Adrian Luca, Horia Ciugudean, ”O depunere rituală ”, p. 18, fig. 7; Iuliu Paul, Cultura Petreşti, Pl. XXIX, Phase A.
} 
that this vessel was also made only (especially) for the ritual purpose of the described archaeological feature. As a form it has analogies in the monography written by I. $\mathrm{Paul}^{27}$. The heigh of the vessel is $9,2 \mathrm{~cm}$, the diameter of the mouth is $15,1 \mathrm{~cm}$ and the diameter of the bottom is 4,4 cm (NMU Alba Iulia, Inv. No. P. 6607).

Vessel with number 6 is small, tronconic (Photo 9-10 - left; P1. V/2) ${ }^{28}$.

The vessel is made of clay mixed with pebbles, brick-like clay on the outside and greyish inside, being well fired. Like Vessels 3-5, it seems to have been made especially for this warehouse, not being carefully finished. It may have been painted (Fig. 8, Pl. I/1), but the painting left only very fine traces. The heigh of the vessel is $3,7 \mathrm{~cm}$, the diameter of the mouth is $8,8 \mathrm{~cm}$, the diameter of the bottom is $2,9 \mathrm{~cm}$ (NMU Alba Iulia, Inv. No. P. 6608).

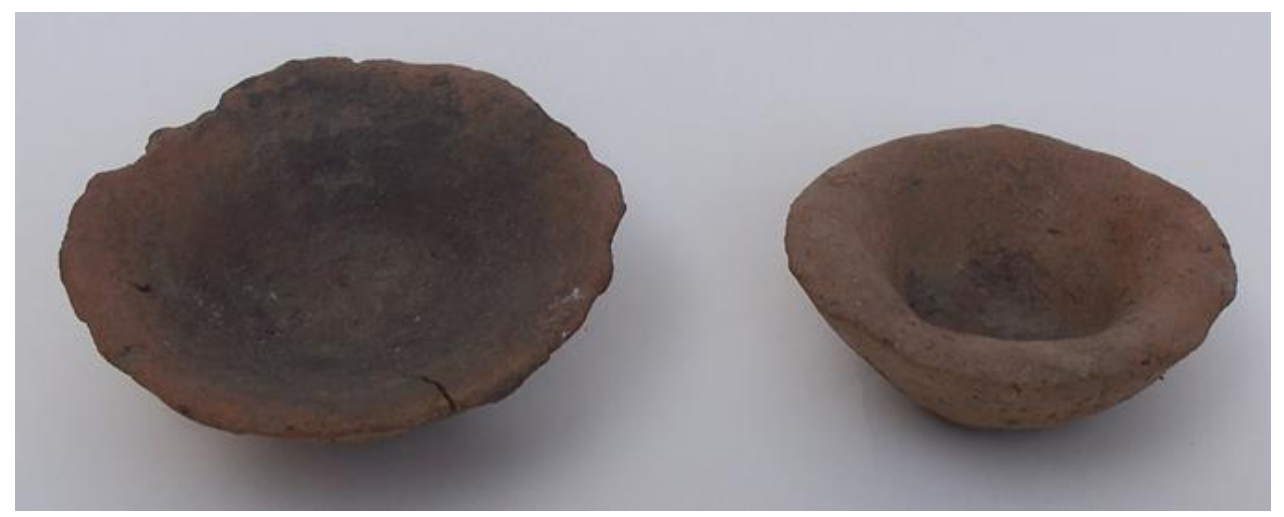

Photo 9. Uioara de Jos-Gruiul lui Şip, Alba County. Small vessels, Petrești culture. Interior (Vessels 6-7).

Vessel number 7 is small and tronconic, having the shape of a vessel for serving liquids (Photo 9-10 - right; Pl. V/1). It is yellowish inside and brown yellowish with greyish firing marks outside, semi-fine and well fired. It belongs to the series of good vessels, made with greater care and used - by all appearances for common use, and outside rituals, as well as vessels 1-2 of this ritual deposit.

The heigh of the vessel is $3,2 \mathrm{~cm}$, the diameter of the mouth is $7,2 \mathrm{~cm}$, the diameter of the bottom is 2,9 cm (NMU Alba Iulia, Inv. No. P. 6609).

\footnotetext{
${ }^{27}$ Iuliu Paul, Cultura Petreşti, Pl. XXIV/9.

${ }^{28}$ Vessels 6-7: Sabin Adrian Luca, Horia Ciugudean, ”O depunere rituală ”, 18-19, Fig. 8.
} 


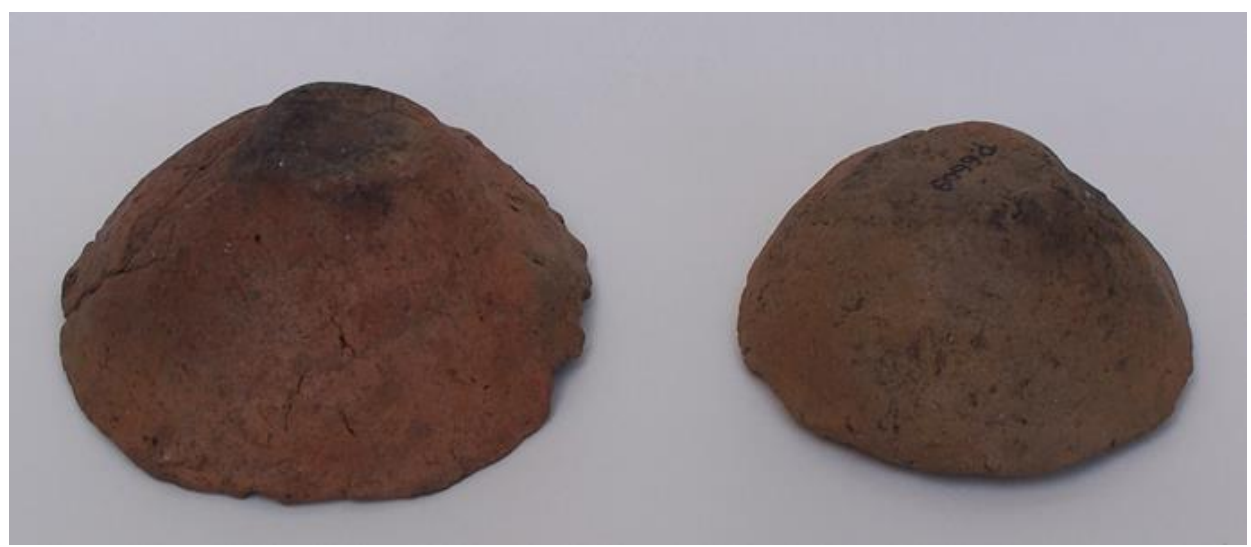

Photo 10. Uioara de Jos-Gruiul lui Şip, Alba County. Small vessels, Petrești culture. Exterior (Vessels 6-7).

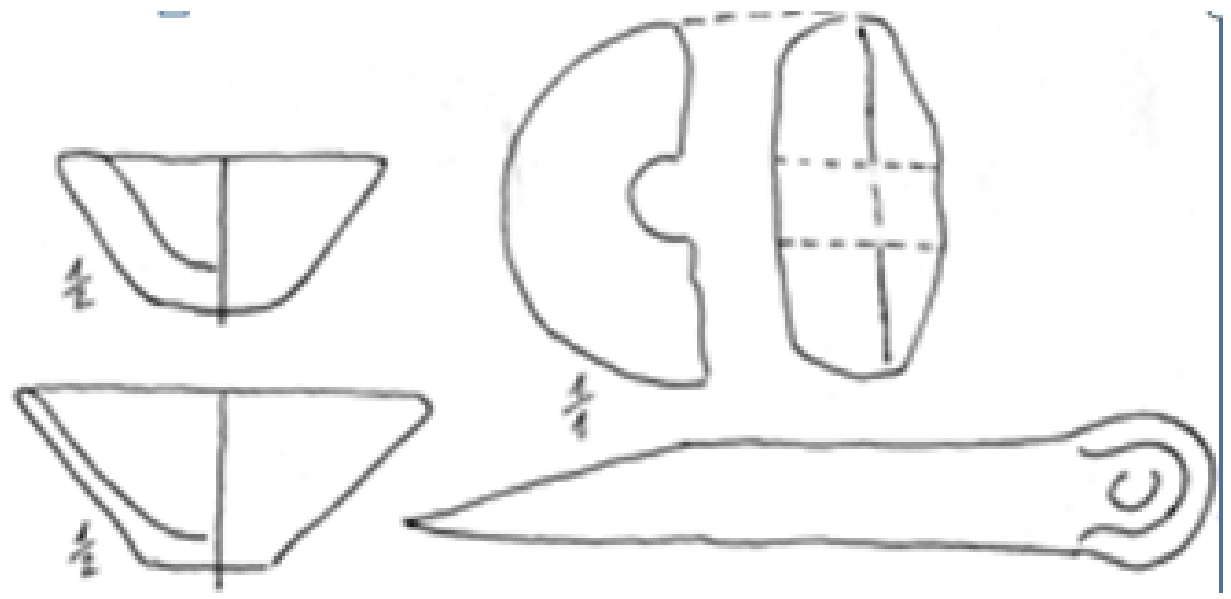

PI. V. Uioara de Jos-Gruiul lui Şip, Alba County. 1 (left-up). Small vessel (Vessel 7); 2 (left-down). Small vessel (Vessel 6); 3 (right-up). Perforated weight, break in two. 4 (right-down). Bone tool.

Piece number 8. The piercer made of bone (Pl. V/4), bird's foot (?) has length of $8,1 \mathrm{~cm}$ (Luca, Ciugudean 2018, 19, Pl. I/7). It was made by cutting/chopping/polishing and seems to have been used for serving food. In the ritual process - which seems to have had a strong food meaning - this tool has it place. Unfortunately, the other bones inside the pit mentioned as part of the pit filling were not researched. We could have - maybe - a better picture of the raw material of the meal (which are the animals approved for such a feast, the parts used by the animal) and how it is cooked (meat). You could see on the bones how to cut them when used for food.

Piece number 9. Fragmentary bi-tronconic spindle made of fired clay (Pl. V/3) (Luca, Ciugudean 2018, 19, Pl. I/6). As most of the times when it comes to 
rituals, the spindle discovered in this ritual pit is broken exactly into two parts, in the pit being only one of them. We would discover hundreds of broken pieces in this way and we never found only one of them (this meant that the piece itself connects with the world of the dead, half belongs to them, their world, and the other half remains on the surface, either to the family, or to their relatives, to the world of living).

Pieces numbers 10-11. Two poor quality flint scrapers (not show) (Luca, Ciugudean 2018, 19 - not show). Unfortunately, the flint pieces were not found. The observation at discovery (poor quality flint) shows us, however, that it is a local raw material, usual, so common.

\section{Conclusions}

Several conclusions are needed analyzing - at least - the composition of the deposit of objects in the feature from Uioara de Jos-Gruiul lui Sip ${ }^{29}$. The vessels in the cult feature published now are of two type:

Type $I$ is that of the vessels used by the community and during daily activities (Vessels 1-2 and 5). We propose this destination based on the more careful way in which they are made, the category, the polish, the way of balancing the ornamental registers and the shapes. But such vessels can undoubtedly have a ritual role. They (the ones discovered on this occasion and in this context) connect with the rituals of the domestic space, being used less often and with a very precise purpose. In our case it is a vessel for storing liquids (Vessel 1), another for serving food - meat, in our opinion (Vessel 2) and a third (Vessel 5) for serving liquids.

Type II belongs to the vessels used only for the ritual process of consecrating the pit (Vessels 3-4 and 6-7). We believe this because they are made, technologically, without too much care, the shapes being a little neatly made, and the painting as well - where it still exists. The general role of one vessel is to store liquids - for suction (vessel 4), and another for serving food - meat, in our opinion (Vessel 3) - and the third role (Vessel 6-7) for serving liquids in small quantities.

We also know that meat was served from Vessels 2-4 and we see it after the burial of a" piercer" (" fork") along with the storage itself. It can also have the purpose of a" fork" because it is made of a bone (of a bird), which splits easily, in environments stronger than this. In meat or other foods, we do not think it can spoil/break very quickly. However, it was only necessary at the time of the unique, ritual feeding.

Vessel 5 can be part - in turn - of category II. In our opinion it is a vessel for heating liquids. The category, the smoothing, and the way of laying the pictorial layer fully show this. Its intentional destruction may be related to its direct use during the ritual process. This ritual can also be linked to the idea of not using it more than once, before burying the warehouse itself. The purpose of half of the spindles discovered on this occasion remains enigmatic.

\footnotetext{
${ }^{29}$ Sabin Adrian Luca, Horia Ciugudean,” O depunere rituală ”, 19-20.
} 
If it was used by a character during his life, and to defend himself, energetically and ritually, we understand why it had to be broken in two exactly. If it had another role, our above proposal is no longer valid. The magical-ritual practices from the time of the Petrești culture are still little known.

Regarding the inclusion in one of the phases of Petrești culture as proposed by I. Paul in the monography that he printed and dedicated to the culture (A, AB or B). By consulting the notes in the quotations up to this page, we see that the vessels are inscribed, according to form or ornaments, each in a different phase.

According to a well-known principle of archaeological thinking:" the newest product (chronologically speaking) from a closed archaeological feature, requires the dating of the whole feature", so we should include the ritual pit from Uioara de Jos-Gruiul lui Șip in the phase B of the Petrești culture.

\section{Pianu de Jos-Podei ${ }^{30}()$}

I. Paul proposed the reconstruction of a possible" cult table" or altar, discovered at Pianul de Jos (Fig. 2; Drawings 1-3) ${ }^{31}$. His approach remained, unfortunately a singular one, even if it would fit - maybe - in this case as well (comparison with Uioara de Jos). The cult complex researched and published by him was near a hearth, a hand grinder, whole and completable vessels ${ }^{32}$.

The fireplace was slightly domed in the middle, and the feature with archaeological materials had nothing around and was $-0,50 \mathrm{~m}$ deep $^{33}$. Ceramic vessels appeared above or in mixture or below, with fragments of adobe ${ }^{34}$. Analyzing, in detail, all the details of the discoveries, I. Paul concludes that we are in front of a table where the discovered ceramic instruments were ${ }^{35}$. The discovered vessels are 10 in number (of which 6 are painted and 4 unpainted - among the unpainted are two incised ornaments - a vessel lid and a careened bowl and two others: a lid and another, large, for storage food or grain $)^{36}$ and were put together by the author in an attempt to recompose the cult table ${ }^{37}$. I also mention the fact that the vessel published by us in drawing 1 seems to have been made especially for this event, being made more carelessly. This archaeological feature can be included in phase B of the Petrești culture.

Two years after the publication of the cult complex I. Paul publishes a consistent article in which we see the general composition in artifacts and cultures

\footnotetext{
${ }^{30}$ Iuliu Paul, "Un complex de cult descoperit în aşezarea neolitică de la Pianul de Jos (r. Sebeș, reg. Hunedoara)". In : StComBruk 12 (1965), p. 5-20; Iuliu Paul, Vorgeschichtliche Untersuchungen in Siebenbüngen (Alba Iulia: 1995), 81-92.

${ }^{31}$ Iuliu Paul, "Un complex de cult", p. 5-20; Iuliu Paul, "Așezarea neo-eneolitică de la Pianul de Jos (Podei), jud. Alba". In: StComBruk 14 (1969), p. 33-88; Iuliu Paul, Cultura Petreşti, Pl. LII/3

${ }^{32}$ Iuliu Paul, "Un complex de cult", 5, Fig. 1-3.

${ }^{33}$ Iuliu Paul, "Un complex de cult", 6.

${ }^{34}$ Iuliu Paul, "Un complex de cult", 8.

${ }^{35}$ Iuliu Paul, "Un complex de cult", 10.

${ }^{36}$ Iuliu Paul, "Un complex de cult", 11-14, Fig. 3-4; Pl. I.

${ }^{37}$ Iuliu Paul, "Un complex de cult", 15, Fig. 4.
} 
of the site from Pianu de Jos-Podei. On this occasion, it was found that the neolithic and eneolithic stratigraphy is made up of the Turdaș, Petrești and Coțofeni cultures, with a great resemblance - with small exceptions - to the Turdaș-Luncă site ${ }^{38}$.

C. Bem has the same observation when he publishes the results of his research in the same and, on the occasion of carrying out the preventive researches carried out on the occasion of laying the foundations of the Orăștie-Sibiu highway ${ }^{39}$.

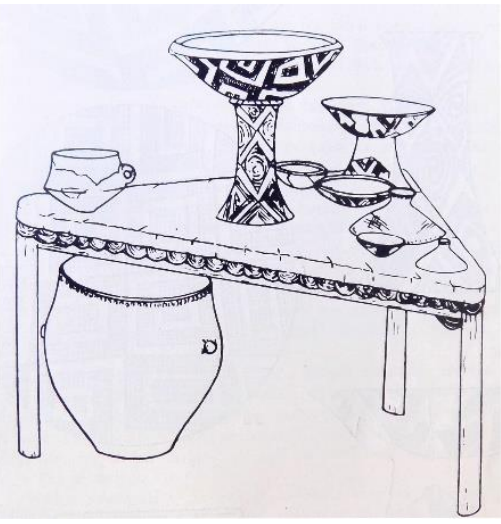

Fig. 2. Pianu de Jos-Podei, Alba County. Reconstruction of the tablealtar.

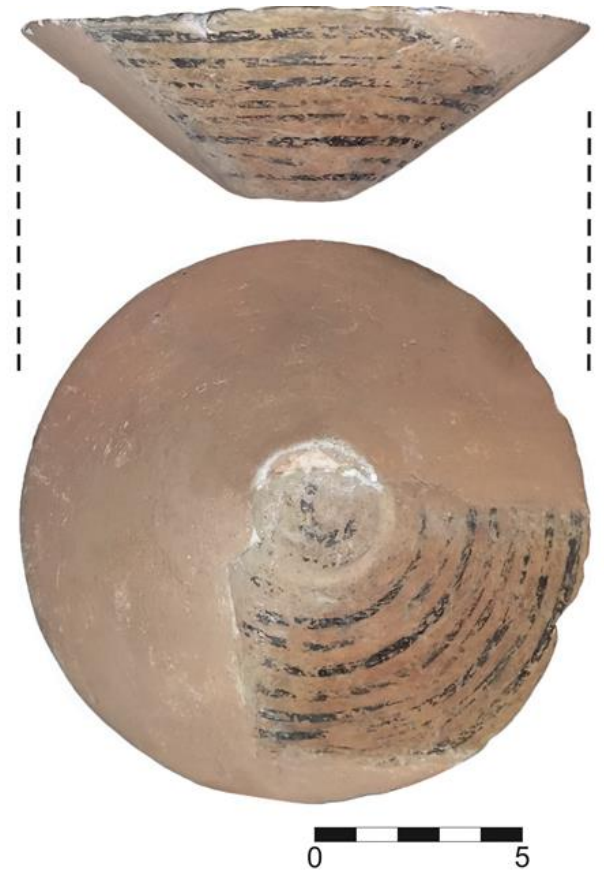

Drawing 1. Pianul de Jos-Podei, Alba County. Painted vessel, inside and outside (Fr. Weinrich) (Paul 1965, 13 (no. 6), Pl. I/6 (p. 12); Pl. II/5, 5a-5b (p. 16)).

\footnotetext{
${ }^{38}$ Sabin Adrian Luca, Așezări neolitice pe Valea Mureșului (II). Noi cercetări arheologice la TurdașLuncă. Campaniile anilor 1992-1995, (Alba Iulia: 2001) BMA 17; Sabin Adrian Luca, Așezări neolitice pe Valea Mureșului (III). Noi cercetări arheologice la Turdaș-Luncă. Campaniile anilor 1996-1998, (Sibiu: Editura Universității Lucian Blaga, 2018) BS 25; Sabin Adrian Luca, Un oraș preistoric din Europa. Turdaș-Luncă. Sector A. I.1, (Sibiu: Editura Universității Lucian Blaga, 2019) BS 26; Sabin Adrian Luca, Un oraș preistoric din Europa. Turdaș-Luncă. Sector B. II.1, (Sibiu: Editura Universității Lucian Blaga, 2019) BS 27.

${ }^{39}$ Cătălin Bem, Sistemul de fortificație al stațiunii eneolitice de la Pianu de Jos Podei (Alba, România). Între simbolism și rațiune, (București: 2018) Monografii 10.
} 


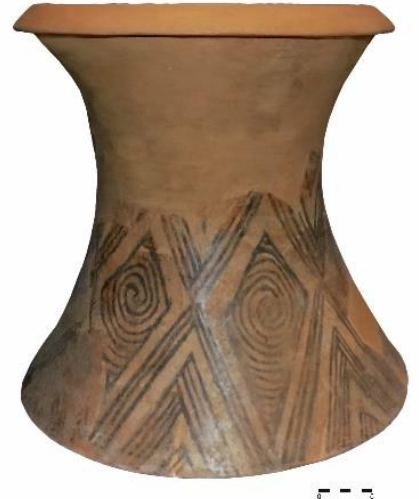

Drawing 2. Pianul de Jos-Podei, Alba County. Painted vessel foot (Fr. Weinrich) (Paul 1965, 52, Pl. IV/2a (p. 54); Paul 1992, Pl. XLV/5).

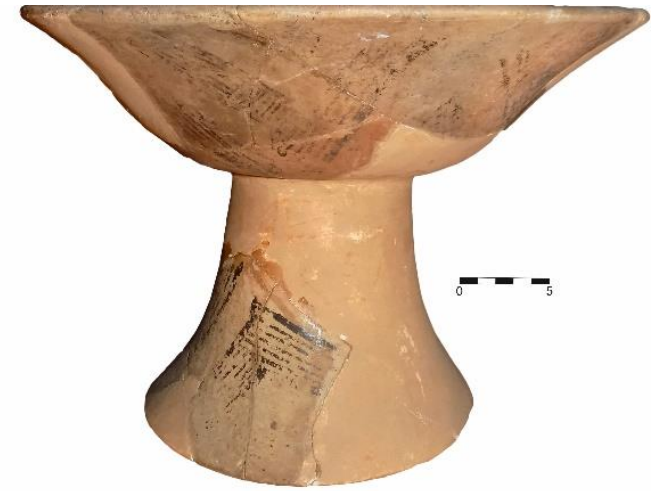

Drawing 3. Pianul de Jos-Podei, Alba County (Fr. Weinrich) Painted vessel footand the painted vessel above it (Paul 1965, 11-13 (nr. 3), Pl. I/3 (p. 12); Pl. II/3 (p. 16)).

A ritual deposit of the Petrești culture was discovered in Sibiu county by M. Macrea (Photo 11; Fig. 3) ${ }^{40}$. This discovery was made in the settlement from Poiana în Pisc ${ }^{41}$. In the surface dwelling and in the hut researched on this occasion, ceramic ${ }^{42}$ and plastic $^{43}$ material specific to the Petrești culture were discovered. Precucuteni materials are also discovered here ${ }^{44}$.

Another important discovery from here is a cult pit that has a number of 1011 whole vessels, among which 6 could be refilled, unadorned, a fragment of a hearth with a garden and a perforated ax, modeled from clay (Fig. 3 - a part in the inventory of the ritual pit $)^{45}$. The vessels were intentionally broken and buried along with coals and other remains from the funeral banquet ${ }^{46}$.

Archaeological materials belonging to the Boian-Giulești and Coțofeni cultures were also discovered in the same archaeological site.

\footnotetext{
${ }^{40}$ Mihail Macrea, ”Șantierul arheologic Cașolț-Boița".In: MCA 7, 1959, 407-444.

${ }^{41}$ Mihail Macrea, "Șantierul arheologic Cașolț-Boița, 421-429.

${ }^{42}$ Mihail Macrea, "Şantierul arheologic Caşolț-Boița, Fig. 20 (Criş tradition! In the vision of the discoverer, but obviously, Petrești).

${ }^{43}$ Mihail Macrea, "Șantierul arheologic Cașolț-Boița, Fig. 21.

${ }^{44}$ Mihail Macrea, "Șantierul arheologic Caşolț-Boița, 425, Fig. 23.

${ }^{45}$ Mihail Macrea, "Șantierul arheologic Cașolț-Boița, 426-429, Fig. 24-25.

${ }^{46}$ Mihail Macrea, ”Șantierul arheologic Cașolț-Boița, 427-428.
} 


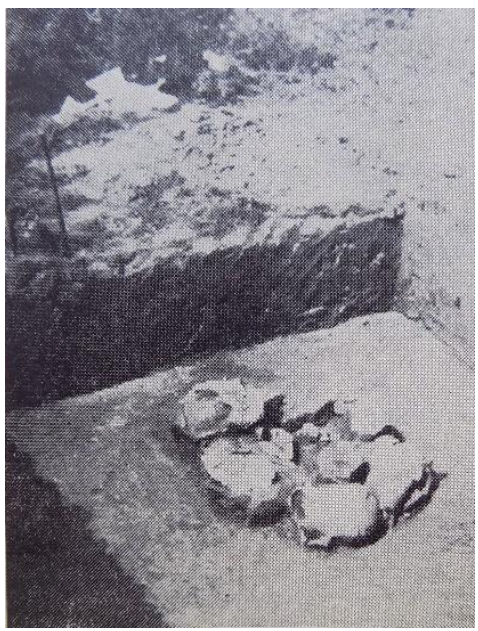

Photo 11. Poiana în Pisc, Sibiu County. The content of the pit.

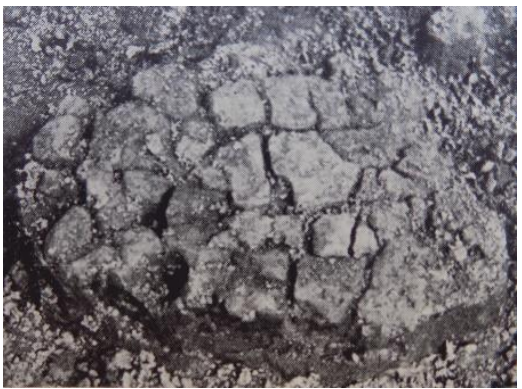

Photo 12. Poiana în Pisc, Sibiu County. Hearth.

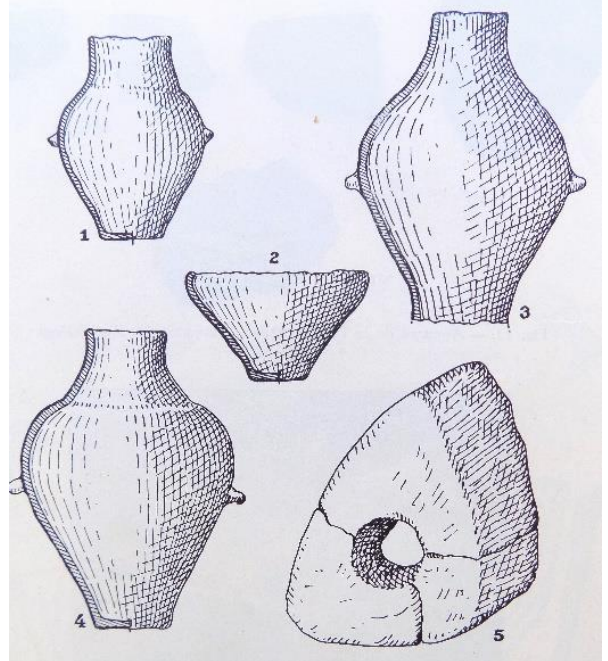

Fig. 3. Poiana în Pisc, Sibiu County. Part of the content of the pit, restored.

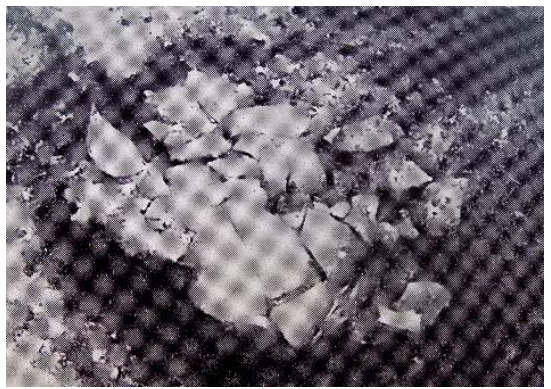

Photo 13. Poiana în Pisc, Sibiu County. Ritual pit.

I. Paul ${ }^{47}$ continues, later, the research from Pioana în Pisc. In addition to two surface dwellings (Photo 12 - hearth of one of them) was discovered a pit (ritual, in the opinion of the discoverer, but also ours) in which were buried two large vessels (Photo 13 - vessels in situ $)^{48}$.

The characteristics of the Petrești settlement from Poiana în Pisc show us an archaeological site of great importance, probably included in one of the beginning sub-phases of the culture (phase A or AB). Remarkable are the special pits, some certainly - rituals, illustrated in this article.

\footnotetext{
${ }^{47}$ Iuliu Paul, "Așezarea neolitică tărzie de la "Poiana în Pisc" (com. Cașolț, raionul Sibiu)". In : MCA, 7 (1961), 107-120.

${ }^{48}$ Iuliu Paul, ”Așezarea neolitică tărzie de la "Poiana în Pisc", 115-116, Fig. 9-10
} 
At Moșna-Râpă/Tablăa, at least three pits were discovered (arranged around or at the edges of a surface dwelling), like the one in Uioara de Jos a deposit of vessels.

The settlement has been mentioned - already - in the literature (photo 14$15)^{49}$. We are reminded of the discovery at this time, and we are not publishing it in its entirety - because the current article is a synthesis, and the full article is being written for printing ${ }^{50}$.

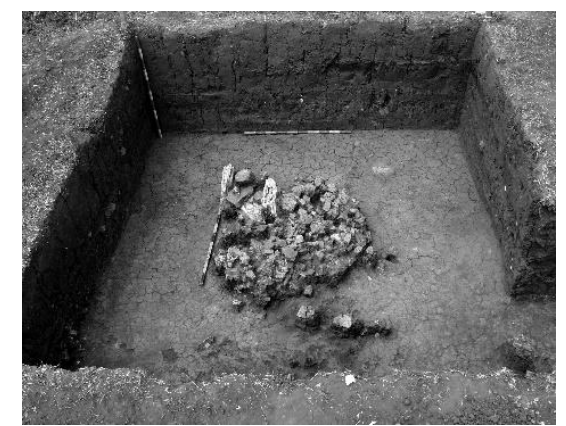

Photo 14. Moșna-Râpă Tablă, Sibiu County. Petrești ritual pit remains.

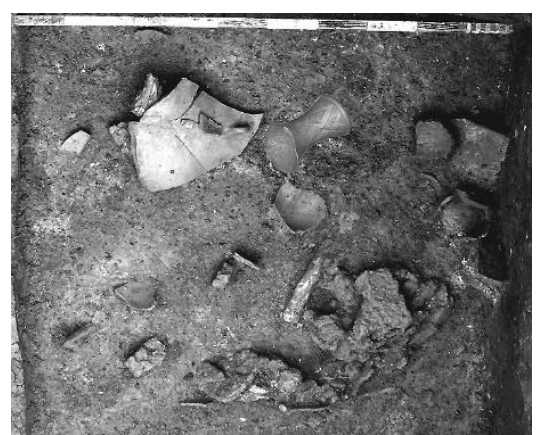

Photo 15. Moșna-Râpă Tablă, Sibiu County. Remains from the bottom of the Petrești ritual pit. Detail with ceramic and osteological fragments, integrable vessels, adobe.

We limit ourselves to starting that in the composition of the filling of this feature is a grinder, adobe and vessels decorated with painting (two are illustrated here, in this article, in photo 16-17), along with others, unpainted. According to all the typological-stylistic characteristics, this archaeological feature can be included in phase $\mathrm{AB}$ and $\mathrm{B}$ of the Petrești culture.

Tărtăria-Gura Luncii. Excavations from 1989, coordinated by I. Paul, led to the discovery - in section I, which I coordinated 0 of a ritual pits filled with painted or unpainted vessels and other archaeological materials. The archaeological material is at the National Museum of the Union in Alba Iulia (excavations were coordinated by I. Paul. The pit is unpublished. Some of the archaeological materials are exhibited in the basic exhibition of the Alba Iulia Museum).

The richness in painted archaeological materials belonging to the Petrești culture from Tărtăria (phase A or AB of the culture) is special. Only the latest publications can be consulted to prove this ${ }^{51}$.

\footnotetext{
49 Lazăr, Georgescu 2004; Gonciar et al 2007; Tincu 2011, 17, Petrești culture. Summary of the doctoral thesis, "Lucian Blaga" University of Sibiu

${ }^{50}$ Luca et al 2021. Contributors: A. Georgescu, A. Gonciar and M.D. Lazăr

${ }^{51}$ Sabin Adrian Luca, Tărtăria REDIVIVA; Sabin Adrian Luca, Florentina Marțiș, Album. Evoluția picturii în situl neolitic și eneolitic de la Tărtăria-Gura Luncii (I), (Sibiu: 2018) BB 75; Sabin Adrian Luca, Ioan Al. Aldea, Album. Evoluția picturii în situl neolitic și eneolitic de la Tărtăria-Gura Luncii (II),
} 


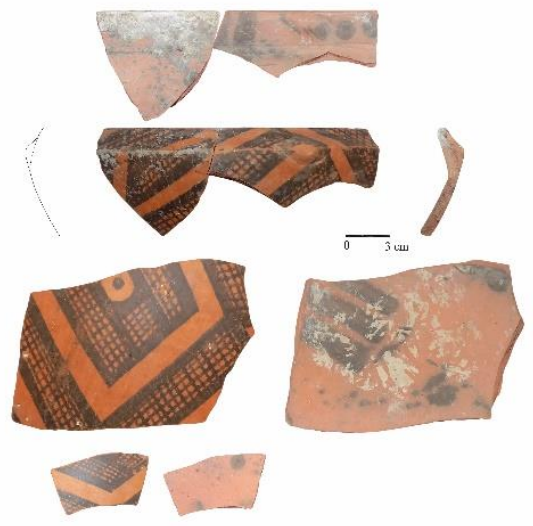

Photo 16. Moșna-Râpă Tablă, Sibiu County. Pit 2. Petrești vessel AB decorated with painting (outside and inside).

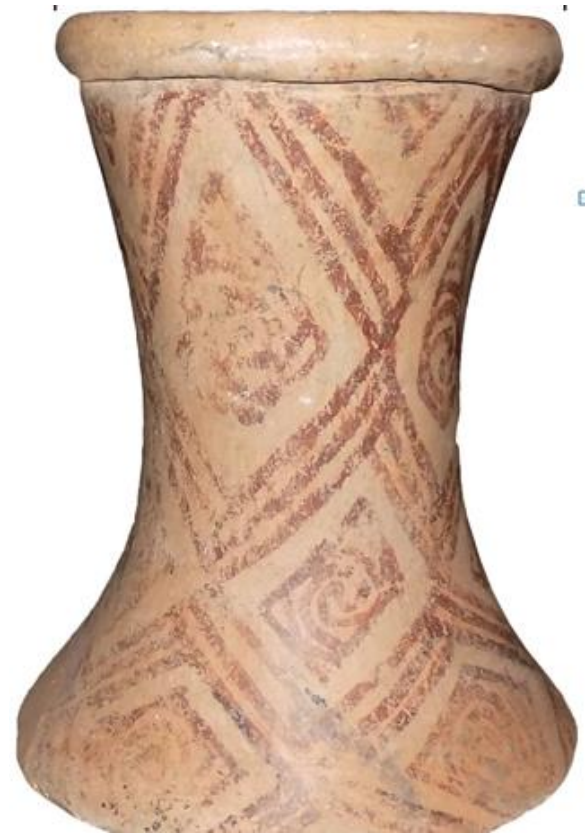

Photo 17. Moșna-Râpă Tablă, Sibiu County. Pit 7. Petrești vessel AB decorated with painting.

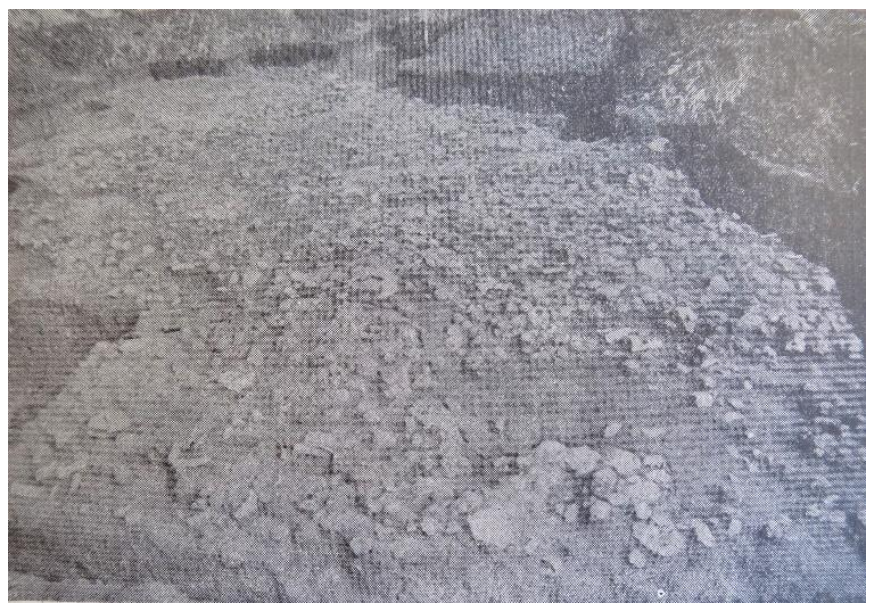

Photo 18. Ghirbom., Alba County. The dwelling near which the ritual complex was discovered. 
Finally, we must mention the ritual archaeological complex from Ghirbom ${ }^{52}$ . The dwelling researched in this site had an agglomeration of archaeological materials that attracted special attention (ceramic vessels - many painted - axes, carved and bone tools $)^{53}$.

Near to this dwelling, or at one of the edges, a ritual deposit was discovered compared to the one from Pianu de Jos-Holm published by I. Paul and mentioned in this article as well. I. Al. Aldea reminds about a cult table and a possible altar in adobe $^{54}$, covered with painting.

Also here was discovered a deer head (made of clay) covered with brown paint - with linear and angular motifs and a clay tablet covered with signs/incisions ${ }^{55}$. There is also a hearth near this feature ${ }^{56}$. The ritual complex consists of 8 vessels $^{57}$, a deer's head ${ }^{58}$ and a clay table ${ }^{59}$.

The component vessels of the ritual complex are published ${ }^{60}$ (Photo 19) separately from the large painted vessel ${ }^{61}$ (Photo 20). Interestingly, the author of the discovery considers that it is followed by a feminine component (imitation of the shape of the woman's body) and the drop is extremely laborious and suggestive, in addition to painted lines and "signs" there are points made with finger (opinion of the author). It is interesting that these points are also inside the vessel.

\section{Conclusions}

Within the Petrești culture is a" fashion”, that of making ritual deposits (usually in pits) that have the following characteristics:

- are usually pits, in association with grinders.

- many of these pits are associated with hearths or adobe.

- when there is increased attention, tools are also found in these archaeological features.

- some of the vessels of the ritual pits are decorated with paintings, with a great diversity of motifs and colors (black, red and white, sometimes in combinations of bichrome or polychrome - trichrome), relatively chronologically framed - especially - in phases $\mathrm{AB}$ and $\mathrm{B}$; it should be noted that the vessels decorated with painting are made by an extremely good technology of mixing, firing and finishing.

\footnotetext{
${ }^{52}$ Ioan Al. Aldea, "Altarul” magico-ritual descoperit în așezarea neolitică de la Ghirbom (com. Berghin, jud. Alba). In: Apulum 7 (1974), p. 40-47

${ }^{53}$ Ioan Al. Aldea, "Altarul" magico-ritual", 40.

${ }^{54}$ With sides around $1 \mathrm{~m}$ - Ioan Al. Aldea, "Altarul" magico-ritual", 43.

${ }^{55}$ Ioan Al. Aldea, "Altarul" magico-ritual", 41.

${ }^{56}$ Ioan Al. Aldea, "Altarul" magico-ritual", 43.

${ }^{57}$ Ioan Al. Aldea, "Altarul" magico-ritual", 43-45.

${ }^{58}$ Ioan Al. Aldea, "Altarul" magico-ritual", 41, 45.

${ }^{59}$ Ioan Al. Aldea, "Altarul" magico-ritual", 41, 45.

${ }^{60}$ Ioan Al. Aldea, "Altarul” magico-ritual", Fig. 2.

${ }^{61}$ Ioan Al. Aldea, “Altarul" magico-ritual”, Fig. 3.
} 
- there are, less frequently, unpainted vessels, decorated with incisions; extremely good mixing, firing and finishing technology is also found - sometimes in these vessels.
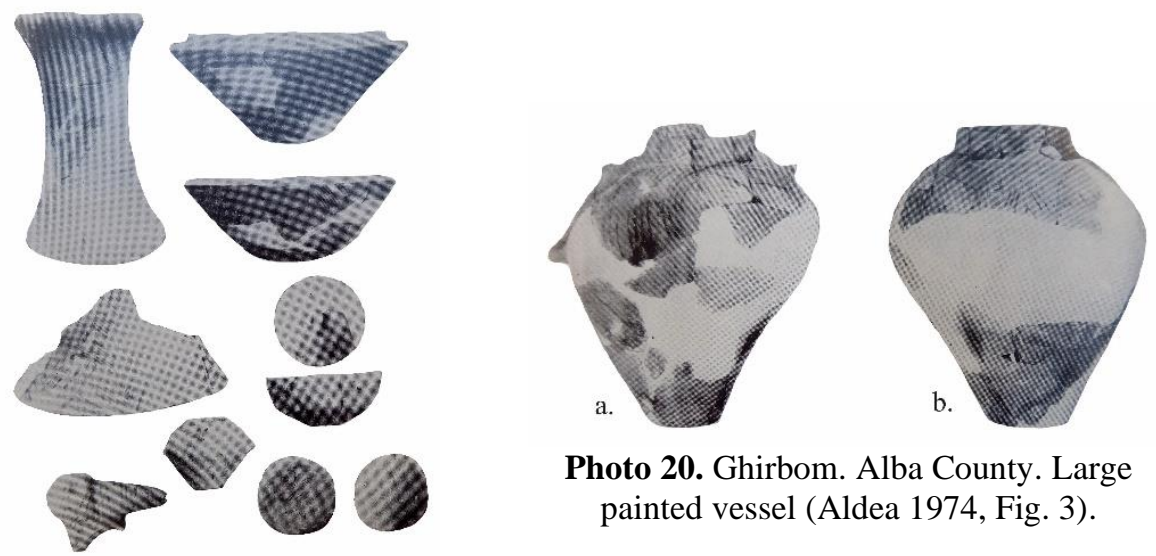

Photo 20. Ghirbom. Alba County. Large painted vessel (Aldea 1974, Fig. 3).

Photo 19. Ghirbom. Alba County.

Some of the archaeological materials of the ritual complex (Aldea 1974, Fig. 2).

$*$

- unpainted vessels - sometimes made, technologically, excellent - are found in all phases.

- there are in these deposits also vessels that seem to be built especially for these rituals.

- the rituals related to these pits are related to eating habits, difficult to individualize, related - perhaps - to feeding, consecration of the quantity and quality of food, but also to" praise" the quantities of food obtained (with food grains - or with meat).

- of course, these rituals are also related to the harvest, the periods of these moments and the worship of specific gods.

- these rituals consecrate - by all appearances - all the dwellings of the Petrești settlements. Some surrounding archaeological cultures" borrow" this custom, along with some of the cult vessels and the specific ritual, by all appearances.

- the ritual of consecrating the dwellings, through banquets dedicated to fertility and fecundity, is so well known at the time, around the Apuseni Mountains, that it is spread in cultural environments west of them. 


\section{Notes}

If most researchers of Romanian prehistory are proud of the art of the Romanian Neolithic ${ }^{62}$, with painted or sculptural pieces created by these civilizations, and in the last great academic synthesis published in 10 volumes, the place of prehistory it is very well covered ${ }^{63}$. In the last two volumes published under the same aegis that reflect art and the evolution of art in Romania ${ }^{64}$, there is no prehistoric art (we are a unique case in Europe, at least!). Chapter I describes Folk art, and Chapter II Art on the territory of Romania from the beginning until the VI century but without illustrated or written references in detail to the Paleolithic, Mesolithic, Neolithic or Eneolithic!

62 Vladimir Dumitrescu, Arta neolitică, (București: 1968); Vladimir Dumitrescu, Arta culturii Cucuteni, (București: 1979); Vladimir Dumitrescu, Alexandru Vulpe, Dacia înainte de Dromichete, (București: 1983).

${ }^{63}$ Istoria Românilor, 2010, (Chapter II., 103-206. Authors: N. Ursulescu, M. Petrescu-Dîmbovița, D. Monah. Petrești culture, 154, Fig. 22. The art-179-188, Fig. 24-29)

${ }^{64}$ Arta din România, Răzvan Theodorescu, Marius Porumb (eds.), (București-Cluj-Napoca: 2018). 


\section{Illustration}

\section{Figures}

Fig. 1. Location of the investigated sites in the area of Ocna Mureș.

Fig. 2. Pianu de Jos-Podei, Alba County. Reconstruction of the table-altar.

Fig. 3. Poiana în Pisc, Sibiu County. Part of the content of the pit, restored.

\section{Drawings}

Drawing 1. Pianul de Jos-Podei, Alba County. Painted vessel, inside and outside (Fr. Weinrich).

Drawing 2. Pianul de Jos-Podei, Alba County. Painted vessel foot (Fr. Weinrich).

Drawing 3. Pianul de Jos-Podei, Alba County (Fr. Weinrich) Painted vessel footand the painted vessel above it.

\section{Photos}

Photo 1. Uioara de Jos-Gruiul lui Şip, Alba County. Painted amphora, Petrești culture (vessel 1).

Photo 2. Uioara de Jos-Gruiul lui Şip, Alba County. Painted amphora, Petrești culture. Detail with the belly of the vessel.

Photo 3. Uioara de Jos- Gruiul lui Şip, Alba County. Painted careened-vessel, Petrești culture (vessel 2).

Photo 4. Uioara de Jos-Gruiul lui Şip, Alba County. Painted careened-vessel, Petrești culture (vessel 2).

Photo 5. Uioara de Jos-Gruiul lui Şip, Alba County. Painted careened-vessel exterior part of the Petrești vessel (vessel 3).

Photo 6. Uioara de Jos-Gruiul lui Şip, Alba County. Painted careened-vessel interior part of the Petrești vessel (vessel 3).

Photo 7. Uioara de Jos-Gruiul lui Şip, Alba County. Bitronconic vessel, Petrești culture (vessel 5).

Photo 8. Uioara de Jos-Gruiul lui Şip, Alba County. Bichrome painted vessel base. Petrești culture (vessel 4).

Photo 9. Uioara de Jos-Gruiul lui Şip, Alba County. Small vessels, Petrești culture. Interior (vessels 6-7).

Photo 10. Uioara de Jos-Gruiul lui Şip, Alba County. Small vessels, Petrești culture. Exterior (vessels 6-7).

Photo 11. Poiana în Pisc, Sibiu County. The content of the pit.

Photo 12. Poiana în Pisc, Sibiu County. Hearth.

Photo 13. Poiana în Pisc, Sibiu County. Ritual pit.

Photo 14. Moșna-RâpăTablă, Sibiu County. Petrești ritual pit remains.

Photo 15. Moșna-RâpăTablă, Sibiu county. Remains from the bottom of the Petrești ritual pit. Detail with ceramic and osteological fragments, integrable vessels, adobe. 
Photo 16. Moșna-RâpăTablă, Sibiu County. Pit 2. Petrești vessel AB decorated with painting (outside and inside).

Photo 17. Moșna-RâpăTablă, Sibiu County. Pit 7. Petrești vessel AB decorated with painting.

Photo 18. Ghirbom. Alba County. The dwelling near which the ritual complex was discovered.

Photo 19. Ghirbom. Alba County. Some of the archaeological materials of the ritual complex.

Photo 20. Ghirbom. Alba County. Large painted vessel.

\section{Plates}

Pl. I. Uioara de Jos-Gruiul lui Şip, Alba County. Painted amphora, Petrești culture (vessel 1).

Pl. II. Uioara de Jos-Gruiul lui Şip, Alba County. Painted careened-vessel, Petrești culture. The vessel is painted outside and inside (vessel 2).

Pl. III. Uioara de Jos-Gruiul lui Şip, Alba County. Painted careened-vessel, Petrești culture. The vessel is painted outside and inside (vessel 3).

Pl. IV. Uioara de Jos-Gruiul lui Şip, Alba County. Bitronconic vessel, Petrești culture. Unpainted (vessel 5).

PI. V. Uioara de Jos-Gruiul lui Şip, Alba County. 1 (left-up). Small vessel (vessel 7); 2 (left down). Small vessel (vessel 6); 3 (right-up). Perforated weight break in two. 4 (right-down). Bone tool. 